University for Business and Technology in Kosovo

UBT Knowledge Center

Fall $10-2020$

\title{
Analiza e kolesterolit me metodtë e kolesterolit me metodë enzimatike në vezë komerciale, ekstensive dhe organike
}

Fjolla VIlasaliu

University for Business and Technology - UBT

Follow this and additional works at: https://knowledgecenter.ubt-uni.net/etd

Part of the Food Science Commons

\section{Recommended Citation}

VIlasaliu, Fjolla, "Analiza e kolesterolit me metodtë e kolesterolit me metodë enzimatike në vezë komerciale, ekstensive dhe organike" (2020). Theses and Dissertations. 13.

https://knowledgecenter.ubt-uni.net/etd/13

This Thesis is brought to you for free and open access by the Student Work at UBT Knowledge Center. It has been accepted for inclusion in Theses and Dissertations by an authorized administrator of UBT Knowledge Center. For more information, please contact knowledge.center@ubt-uni.net. 


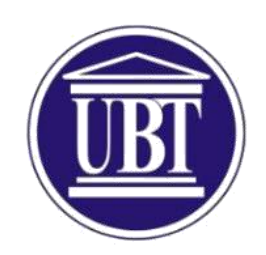

Kolegji UBT

Fakulteti i Shkencave të Ushqimit dhe Teknologjisë

\section{ANALIZA E KOLESTEROLIT ME METODË ENZIMATIKE NË VEZË KOMERCIALE, EKSTENSIVE DHE ORGANIKE}

Tetor, 2019

Prishtinë 


\title{
UBI
}

Kolegji UBT

Fakulteti i Shkencave të Ushqimit dhe Teknologjisë

Punim Diplome

Viti akademik 2016-2017

Fjolla Vllasaliu

ANALIZA E KOLESTEROLIT ME METODË ENZIMATIKE NË VEZË KOMERCIALE, EKSTENSIVE DHE ORGANIKE

\author{
Mentori: Valon Durguti
}

Tetor, 2019

Ky punim është përpiluar dhe dorëzuar në përmbushjen e kërkesave të pjesshme për Shkallën Bachelor 


\begin{abstract}
Abstrakti
Përqendrimi i kolesterolit në tre lloje të vezëve është analizuar përmes metodës enzimatike. Llojet e vezëve të analizuara kanë qenë: vezë komerciale, vezë ekstenzive dhe vezë organike. Janë analizuar gjithsej tridhjetë e pesë mostra. Marrja e mostrave ka qenë e rastësishme dhe analiza e kolesterolit është bërë me anë të spektrofotometrit GENESYS 10S UV-Vis. Analizat janë kryer në laboratorët hulumtues të Universitetit për Biznes dhe Teknologji (UBT) - Kosovë. Mesatarja e rezultateve të marra tregon për një përqendrim pak më të ulët të kolesterolit në llojin e vezëve ekstensive në krahasim me llojet e tjera të analizuara.
\end{abstract}




\section{Falënderimi}

Falënderoj nga zemra prindërit që më kanë përkrahur që nga dita e parë e studimeve, i falënderoj ata për durimin, këshillat dhe mbështetjen e pakusht. Falënderoj mentorin tim që më ka ndihmuar në realizimin e kësaj teme. Falënderoj poashtu edhe të gjithë stafin akademik dhe atë menaxhues të fakultetit për kontributin e dhënë gjatë studimeve. 


\section{PËRMBAJTJA}

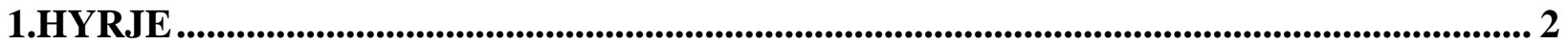

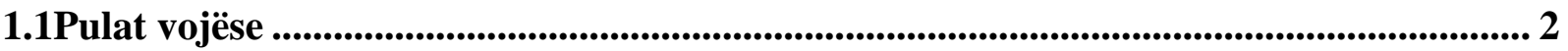

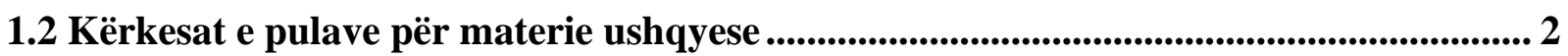

1.2.1 Kërkesat për lëndë yndyrore ................................................................................. 3

1.2.2 Kërkesat për lëndë minerale............................................................................ 4

1.2.3 Kërkesat për vitamina............................................................................................ 4

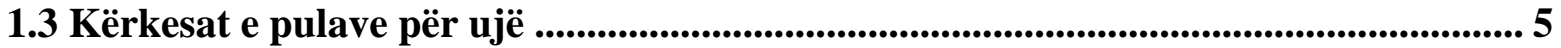

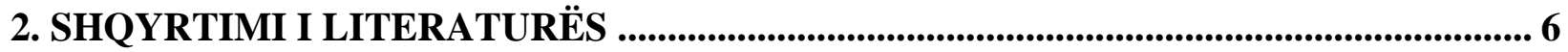

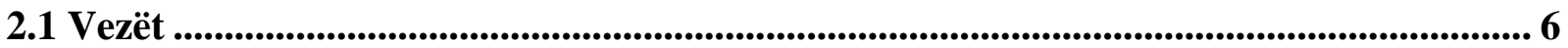

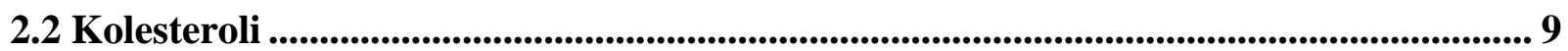

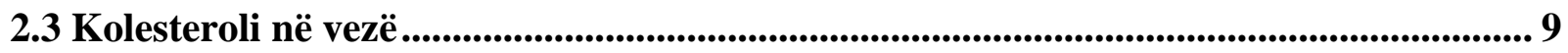

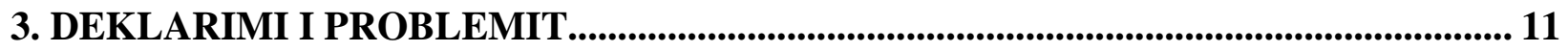

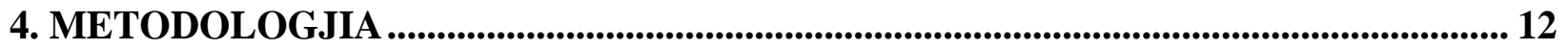

4.1 Mostrimi dhe përgatitja e mostrave ....................................................................................... 12

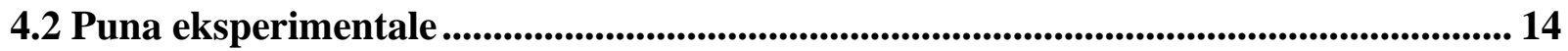

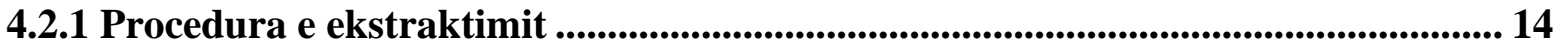

4.2.2 Parimi i veprimit enzimatik të reagjentit të kolesterolit ....................................... 15

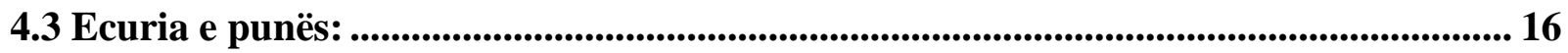

5. PREZANTIMI DHE ANALIZA E REZULTATEVE ................................................... 18

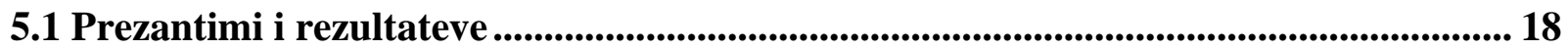

5.2Analiza e rezultateve ........................................................................................................................ 21

6. KONKLUZIONE DHE REKOMANDIME ..................................................................... 24

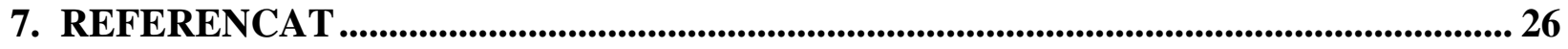




\section{LISTA E FIGURAVE}

Figura 1. Ambienti ku kullosin pulat që ushqehen në mënyre organike... 12

Figura 2. Ambienti i fermës ekstensive..........................................13

Figura 3. Përgatitje për ekstraktim të mostrave .................................... 15

Figura 4. Kolesteroli total në të kuqen e vezëve komerciale..............................18

Figura 5. Kolesteroli total në të kuqen e vezëve ekstenzive.................................19

Figura 6. Kolesteroli total në të kuqen e vezëve organike................................20

\section{LISTA E TABELAVE}

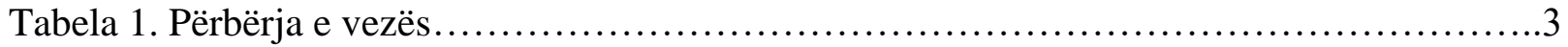

Tabela 2. Tabela e ushqimit të pulave për periudhën starter...........................13

Tabela 3. Tabela e ushqimit të pulave për periudhën grover...............................14

Tabela 4. Tabela e ushqimit të pulave për periudhën finisher...............................14

Tabela 5. Përbërësit për kryerjen e eksperimentit.....................................17

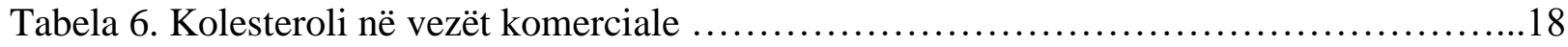

Tabela 7. Kolesteroli në të kuqen e vezëve ekstensive...............................19

Tabela 8. Kolesteroli në të kuqen e vezëve organike ...................................20 


\section{FJALORI I TERMAVE}

Ca: P - Raporti kalcium fosfor

PRM- Mish i Kuq i Përpunuar (Processed Red Meat)

RDA- Lejimi ditor i rekomanduar (Recommended Dietary Allowance)

NCEP- Programi kombetar i edukimit mbi kolesterolin (National Cholesterol Education Program)

FAO- Organizata Botërore e Ushqimit (The Food and Agriculture Organization)

UV-VIS- Spektri Ultravjollcë dhe i Dukshëm

EGG IEC- Komisioni Ndërkombëtar për Vezë (International Egg Comission)

HDL- Lipoproteina me Densitet të Lartë (High-Density Lipoprotein)

LDL- Lipoproteina me Densitet të Ulët (Low-Density Lipoprotein)

CVD - Sëmundjet kardiovaskulare (Cardiovascular Diseases)

AHA- Shoqata Amerikane e Zemrës (American Heart Association) 



\section{HYRJE}

\subsection{Pulat vojëse}

Pulat vojëse janë anëtarë të një rendi të njohur si Aves. Për dallim prej shumë zogjve të tjerë, pulat kategorizohen si një produkt, që i mungon autenticiteti si një kafshë e vërtetë me një histori evolucionare dhe kontekstin filogjenetik. Pulat vojëse (shtëpiake) kanë preardhje nga shpendët e kuq të xhunglës (Gallus gallus). Ato konsiderohen një nënlloj i homologëve të tyre të egër, të cilët banojnë në skajet e fushave, kopshtet dhe shkurret në Indi dhe Azinë Juglindore. Domestikimi i shpendëve të kuq të xhunglës u krijua mirë nga 8000 vjet më parë, por studimet molekulare sugjerojnë se mund të kishte filluar qysh para 58,000 vjet më parë. Si pasojë, ato u përhapën globalisht për prodhimin e mishit dhe vezëve. Shumë varibale të tilla si raca, mosha, ushqimi, metoda e prodhimit, seksi, përpunimi etj mund të ndikojnë në vlerat ushqyese të mishit të pulës. Pula mund të kontribuojë në një model të shëndetshëm të të ngrënit. Është një burim i rëndësishëm i proteinave. Prerja dhe konsumimi mbizotërues, mishi i gjirit, është i ulët në yndyrë, me profilin e tij lipidik duke favorizuar acidet yndyrore të pangopura, e rrallë herë acidet yndyrore të ngopura.

Mishi i pulës jep vitamina dhe minerale thelbësore dhe është burimi më i përballueshëm i mishit për njerëzit. Më shumë se 50 miliardë pula rriten çdo vit si burim ushqimi, kuptohet për vezët e tyre dhe mishin. Mesatarisht, një pulë vojse prodhon një vezë / ditë. Të gjithë pulat vojse fillojnë të shtrihen saktësisht kur ato janë 21 javë të vjetër. Prandaj, kërkohet që planifikimi e prodhimit të vezëve të jetë konstant për të përmbushur kërkesat e tregut. Në zonat ku klima është e nxehtë dhe e lagësht, pulat vojse hibride komerciale prodhojnë mesatarisht midis 180 dhe 200 vezë në vit. Në rajonet që karakterizohen me klimë më shumë të butë pulat vojse mund të prodhojnë mesatarisht midis 250 dhe 300 vezë në vit. Pulat e egra plotësojnë nevojat e tyre natyrshëm, megjithatë zhdukja e pulave ka krijuar mjedise dhe kufizime të reja. Pulat që janë pjesërisht ose plotësisht të mbyllura, kërkojnë që njeriu të sigurojë ato nevoja të cilat nuk mund të sigurohen natyrshëm të tilla si: sigurimi i ujit dhe ushqimit; strehimi dhe / ose ventilimi; ndriçim artificial; pastrimi dhe / ose dezinfektimi i objekteve, etj.

\subsection{Kërkesat e pulave për materie ushqyese}

Racionet mund të përbëhen përmes këtyre ushqimeve: ushqimet energjike - përbëjnë $70 \%$ të racioneve të pulave. Në këtë grup hyjnë: misri dhe gruri e më rrallë elbi, tërshëra etj. 
Ushqimet proteinike: ndahen në dy grupe, në ushqime proteinike me prejardhje bimore dhe ushqimet proteinike me prejardhje shtazore. Ndër ushqimet proteinike me prejardhje bimore që më së shumti përdoren për përgatitjen e racioneve të pulave janë: bërsitë vajore (bërsia e sojës, e lulediellit dhe e kolzës), tharmëza e birrës, himet e grurit, mielli i jonxhës etj.

Bërsia e sojës është përbërësi kryesorë proteinik i racioneve të pulave të reja dhe në racionet e tyre merr pjesë deri 25\%. Bërsia e lulediellit për shkak të përmbajtjes së lartë të celulozës merr pjesë në sasi më të kufizuar kurse në racionet e pulave të rritura mund të inkuadrohet maksimumi $15 \%$. Tharmëza e birrës përmban $40-60 \%$ proteina dhe është e pasur me vitamina të kompleksit B, për këtë arsyje përdoret më së tepërmi. Në racionet e pulave merr pjesë me 1-2\%. Mielli i jonxhës së dehidruar përveç qe është burim i proteinave në racionet e shpendëve kryesisht përdoret për marrjen e karotinës.Nga ushqimet proteinike me prejardhje shtazore më së tepërmi përdoret: mielli i peshkut, mielli i mishit, mielli i mishit dhe eshtrave, mielli i puplave, mielli i mëlçisë, gjakut etj. Sasia e këtyre ushqimeve në racionet e pulave është e kufizuar (deri 6\%) për shkak se karakterizohen me aromë jo të përshtatshme (me këtë rast aroma përcillet edhe në prodhim) dhe gjithashtu kosto e tyre është tejet e lartë.

Ushqimet minerale- kërkesat në lëndë minerale te pulat plotësohen përmes shkumësit të kafshëve pastaj mono, dy dhe tre kalcium fosfatit, miellit të eshtrave, kripës së jodizuar, dhe shtresave të posaçme të mikroelementeve - premikseve. Kërkesat për minerale veçanërisht, janë të larta, te pulat që janë të destinuara për prodhimin e vezëve. Që të sigurohet sasi më e madhe e kalciumit dhe të stimulohet bluarja më e mirë e ushqimit, pulave që mbahen në mënyrë të lirë ose gjysmë industriale, përmes ushqimit mund të $\mathrm{u}$ jepet edhe një sasi e rërës.

Në pulari industriale, ku pulat nuk dalin të lira në kullotë, racionet e tyre duhet të përmbajnë edhe shtesa të veçanta të vitaminave, antibiotikëve, kokcidiostatikëve, lëndëve pigmentuese etj. Për disa kategori të pulave (brojlerëve) në racion shtohet edhe yndyra përmes së cilës sigurohet sasi e mjaftueshme e energjisë.

Mund të konkludohet se të ushqyerit e pulave bazohet në ushqimet komplete të koncentruara me vlerë të lartë biologjike të proteinave, me vlerë të lartë energjike, mirë të balancuara në përmbajtje të aminoacideve, vitaminave, makro e mikroelementeve etj. Gjithashtu, racionet për pula duhet të jenë me tretshmëri të lartë dhe me sasi të ulëta të celulozës. Këto racione janë me çmime të larta prandaj mund të shpërblehen (paguhen) vetëm me prodhimtari të lartë të vezëve dhe mishit. 
Shpendët kanë nevojë për një numër të madh të lëndëve ushqyese, por në të ushqyerit e shpendëve kryesisht flitet për kërkesat në energji, proteina, lëndë minerale dhe vitamina. Kërkesat e pulave për lëndë ushqyese janë të shumta varësisht nga lloji, kategoria dhe faza e prodhimtarisë së shpendëve. Tretshmëria e karbohidrateve te pulat arrin deri 50\% (përveç celulozës e cila te pulat nuk tretet), yndyra tretet $80-90 \%$, kurse proteinat $85 \%$. Kërkesat e pulave për energji varen nga prodhimtaria dhe kushtet e kultivimit të tyre.

Energjia në racionet e pulave llogaritet në energji metabolike ose produktive dhe shprehet në kJ (kilo xhul). Energjia metabolike për kategorinë e pulave vojse është $11053-13356 \mathrm{~kJ} / \mathrm{kg}$ ushqim në ditë.

Kërkesat për proteina janë më të larta në krahasim me lloje tjera kafshëve dhe drejtpërdrejt e lidhur me sasinë e energjisë në racionet e pulave. Sasia e tyre në racion paraqitet në (\%) dhe ndryshon varësisht nga kategoria faza e prodhimtarisë, mosha, temperatura dhe kushtet e strehimit. Sa më e lartë të jetë vlera energjike e racionit edhe sasia e proteinave duhet të rritet. Kështu raporti në mes energjisë dhe proteinave në ushqim është vendimtar për zhvillimin e pulave dhe prodhimtarisë së tyre.

Në të ushqyerit e shpendëve përveç në sasinë e proteinave duhet pasur kujdes edhe në cilësinë e tyre, gjegjësisht prezencën e aminoacideve, pasi që sintetizimi i aminoacideve në traktin digjestiv të shpendëve praktikisht nuk ekziston. Në praktikën e të ushqyerit të kategorive të ndryshme të pulave, posaçërisht duhet pasur kujdes në këto aminoacide: lizinë, metioninë, triptofan, cistinë dhe argininë.

Vlera e lartë biologjike e proteinave për pula vojse sigurohet përmes ushqimeve shtazore, të cilat në racionet e pulave jepet prej 3-10\%. Kërkesat e pulave për proteina dhe aminoacide esenciale është 15.0 - $16.5 \%$.

\subsubsection{Kërkesat e pulave për lëndë yndyrore}

Për pula është me rëndësi që në racionet e tyre të kenë sasi të mjaftueshme të acideve yndyrore esenciale, gjegjësisht acid linolik dhe linoleik. Zakonisht në ushqimin e pulave ndodhen sasi të mjaftueshme të yndyrës që i plotëson kërkesat në këto acide të pangopura yndyrore. Mungesa e tyre në racion shkakton uljen e prodhimtarisë dhe paraqitjen e sëmundjeve të ndryshme. Kërkesat në acid linoleik te zogjtë janë prej 0.8-2\%, kurse te pulat për vezë prej 1.0-1.4\%.

\subsubsection{Kërkesat e pulave për lëndë minerale}


Pulat kanë kërkesa të mëdha për lëndë minerale posaçërisht në kalcium dhe fosfor. Kërkesat e zogjve në kalcium janë prej $0.8-1.0 \%$, kurse te pulat për vezë 3.0-3.5\%. Kërkesat për fosfor të shfrytëzueshëm janë prej $0.5-0.55 \%$. Nga sasia e tërësishme në racionin e pulave rreth $70 \%$ duhet të jetë me prejardhje nga burimet joorganike (dikalcium fosfati mielli i eshtrave), pasi që është konstatuar se vetëm 30\% të fosforit nga ushqimet me prejardhje bimore është inorganik dhe i shfrytëzueshëm për pulat. Kërkesat e pulave vojse në kalcium janë të larta pasi që lëvozhga e vezës është e përbërë nga karbonati i kalciumit dhe në rast të mungesës së Ca në racion, lëvozhga do të jetë e butë dhe lehtë thyhet. Raporti Ca:P në racionin e pulave voje duhet të jetë 4:1. Derisa kërkesat në makroelemente paraqiten në \%, kërkesat në mikroelemente shprehen në miligram në ushqimet përkatëse. Nga mikroelementet rëndësi të madhe ka Mangani,

\subsubsection{Kërkesat e pulave për vitamina}

Pulat karakterizohen me prodhimtari të lartë dhe procese metabolike intensive,kërkesat në vitamina janë tejet te larta në krahasim me sasinë e konsumuar. Posaçërisht, kërkesa të mëdha kanë për vitaminat A dhe D të cilat mundësojnë rritjen intensive të zogjve për majmëri, rrisin vlerën e inkubimit të vezëve, përqindjen e vezëve të çelura dhe e rrisin vitalitetin e zogjve të çelur. Këto vitamina, janë të rëndësishme edhe për pulat për vojse, meqë vezët janë burim i mirë i vitaminave 5.A dhe D në të ushqyerit e njeriut. Njerëzit mjaft mirë e shfrytëzojnë karotinën, si burim të vitaminave A dhe D nga shpendët.

Pulave ju jepet vitamina D në formë të D-3, e cila është më efikase në krahasim me formën D2, e sidomos kur në racionet e zogjve ndodhen sasia më të ulëta të fosforit inorganik. Sasia e vitaminës E, në racionet e pulave është e varur nga sasia e acideve yndyrore të pangopura dhe prania e antioksidantëve në ushqim.

Prezenca e acideve yndyrore të pangopura në ushqim rritë kërkesën për vitaminën E. Ndërkaq, prezenca e antioksidantëve, zvogëlon kërkesat për vitaminën E. Edhe seleni, pjesërisht ndikon në uljen e kërkesave për vitaminën E. Duke u bazuar në përbërjen e ushqimit të shpendëve (t, yndyra) kërkesat e shpendëve në grupin e vitaminave të kompleksit B janë të larta. Më të rëndësishme, për pulat, janë: vitamina B-2, acidi nikotinik, acidi folik dhe holina. Kërkesat në vitamina dhe mikroelemente janë të varura edhe nga raca apo hibridi i pulave. Kështu, raca Plimutrok, ka kërkesa më të mëdha për vitaminën B dhe mangan në krahasim me racën Leghorn.

\subsubsection{Kërkesat e pulave për ujë}


Pulat zakonisht furnizohen me ujë përmes pirësve automatik të dedikuara për këtë lloj të shpendëve. Në prodhimtarinë intensive pulat ushqehen vetëm me ushqime të thata, prandaj ujin duhet ta kenë gjithnjë në dispozicion dhe ta shfrytëzojnë sipas dëshirës. Preferohet që pulave për veze gjatë prodhimtarisë maksimale te vezëve t'ju sigurohen rreth $225 \mathrm{ml}$ ujë në ditë, kurse zogjve në majmëri rreth $100 \mathrm{ml}$ ujë të freskët në ditë. Raporti në mes ushqimit dhe ujit duhet të jenë në raport 1:2.

\section{SHQYRTIMI I LITERATURËS}


Vezët janë një nga ushqimet e pakta që përdoren në të gjithë botën, pavarësisht fesë dhe grupit etnik.Veza është si një kuti e mbyllur me një strukturë të jashtme të përshtatshme për të siguruar cilësinë e saj të brendshme. Lëvozhga në thelb është e përbërë nga CaCO3 (98\%), në një strukturë polikristaline në shtresa paralele që formojnë nyjën gjitare, duke krijuar në mbi 8000 pore që shërbejnë për shkëmbimin e gazit brenda dhe jashtë vezës. Bërthama e brendshme ushqyese ka dy ndarje të cilat janë albumina (59\%) dhe e verdha e vezës (31\%), ku gjenden lëndët ushqyese kryesore për konsum njerëzor. Shumica e ushqyesve thelbësorë janë në të verdhën e vezëve dhe veçanërisht vitaminat e tretshme në yndyrë, të pranishme specifikisht në këtë pjesë. Gjithashtu acidet yndyrore esenciale dhe seritë omega-3 janë të pranishme në të verdhën e vezës. (Bertechini A. $G, 2013)$. Konkretisht, vezët përbëhen nga 3 elementë kryesorë: lëvozhga e vezës (9-12\%), e bardha e vezës (60\%) dhe e verdha e vezës (30-33\%). E gjithë veza përbëhet nga uji (75\%), proteinat (12\%), lipidet (12\%), duke përfshirë edhe karbohidratet dhe mineralet (1\%).

Veza konsiderohet si ushqimi më i përsosur i natyrës, që përmban burim të shkëlqyer të proteinave me vlera të larta biologjike, me raport të lartë të acideve yndyrore të pangopura ndaj acideve yndyrore të ngopura dhe burim i shkëlqyer i mineraleve me të gjitha vitaminat. Vitamina C dhe niveli i ulët i kalciumit janë të vetmit ushqyes që mungojnë në vezë. Proteinat e pranishme në vezë shpërndahen midis të bardhës së vezës dhe të verdhës së vezëve, ndërsa lipidet janë të përqendruara kryesisht në të verdhën e vezës. E verdha e vezës përmban të gjithë yndyrën dhe gjysmën e proteinave, pjesën më të madhe të kalciumit, fosforit, hekurit, zinkut, dhe vitaminat B6, B12, A, me acidin folik, gjysmën e riboflavinës dhe tianinës. E bardha e vezës përmban rreth gjysmën e proteinave dhe riboflavinën (H. Sunëoo H. et al. 2014). E bardha e vezëve kryesisht përbëhet nga uji (88\%) dhe proteinat (11\%), me pjesën e mbetur të përbërë nga karbohidrate, hiri dhe sasi të gjurmëve të lipideve (1\%). Ovalbumina (54\%), ovotransferina (12\%), ovomucoidi (11\%), lizozomet (3.5\%), dhe ovomucina (3.5\%) konsiderohen si proteinat kryesore së bashku me avidinat (0.05\%), cistatinat (0.05\%), ovomakroglobulina $(0.5 \%)$, ovoflavoproteina $(0.8 \%)$, ovoglikoproteina $(1.0 \%)$ dhe ovoinhibitori $(1.5 \%)$ të cilat janë mikroproteina që gjenden në të bardhën e vezës. E verdha e vezës është e mbuluar me membranë viteline ku kryesisht përbëhet nga uji (50\%), proteina (15-17\%), lipide (31-35\%), dhe karbohidrate (1\%). Proteinat e pranishme në të verdhën e vezëve përbëhen nga lipovitelina (36\%), livetina (38\%), fosvitina (8\%) dhe lipoproteina me densitet të ulët (17\%). Gjithashtu, e verdha e vezës përmban $1 \%$ karotinoide, gjë që e bën atë me ngjyrë të verdhë (Abeyrathne,2013). 
Vezët mund të japin një kontribut të rëndësishëm në një dietë të shëndetshme. Një vezë me madhësi të mesme siguron $78 \mathrm{kcal}$, megjithatë përmban $6.5 \mathrm{~g}$ proteinë. Përmbajtja e yndyrës është $5.8 \mathrm{~g}$, prej të cilave $2.3 \mathrm{~g}$ janë yndyra të pangopura (Tabela 1 ). Vezët përmbajnë një shumëllojshmëri të vitaminave, mineraleve dhe elementëve gjurmë të rëndësishme. Sipas rregullores së "European Commission (EC) Nutrition \& Health Claims" (Parlamenti Evropian dhe Këshilli, 2007) një 'burim ushqimor' mund të bëhet produkt ushqimor nëse plotëson të paktën $15 \%$ të shumës së rekomanduar ditore (RDA) për 100g, ndërsa një ushqim 'i pasur me vlera të mëdha ushqyese' cilësohet kur $\begin{array}{lllll}\text { nivelet } & \text { ushqyese } & 30 \% & \text { tejkalojnë }\end{array}$ Provat e reja sugjerojnë se ngrënia e vezëve është e lidhur me ngopjen, menaxhimin e peshës dhe cilësinë më të mirë të dietës. Për më tepër, antioksidantët që gjenden në të verdhën e vezës mund të ndihmojnë në parandalimin e degjenerimit makular të lidhur me moshën. Analiza dytësore tregoi se konsumatorët e rregullt të vezëve me një konsum të ulët të mishit të kuq dhe të përpunuar (RPM) që hanë dieta më të shëndetshme kishin një status mikronutrient më të mirë se ata që nuk hanin vezë, por që kishin një konsum të lartë të RPM. Është arritur në përfundimin se konsumi i vezëve, në një gamë të marrjeve, shoqërohej me ushqyeshmëri të mirë dhe përfitime shëndetësore (Ruxton, 2010). 


\begin{tabular}{cccc} 
Component (Unit) & Amount & Component $($ Unit) & Amount \\
\hline Egg shell $(\%)$ & 10.5 & Calcium $(\mathrm{mg})$ & 56.0 \\
Egg yolk $(\%)$ & 31 & Magnesium $(\mathrm{mg})$ & 12.0 \\
Egg white $(\%)$ & 58.5 & Iron $(\mathrm{mg})$ & 2.1 \\
Water $(\mathrm{g})$ & 74.5 & Phosphorus $(\mu \mathrm{g})$ & 180.0 \\
Energy $(\mathrm{Kcal})$ & 162 & Zinc $(\mathrm{mg})$ & 1.44 \\
Protein $(\mathrm{g})$ & 12.1 & Thiamine $(\mathrm{mg})$ & 0.09 \\
Carbohydrates $(\mathrm{g})$ & 0.68 & Riboflavin $(\mathrm{mg})$ & 0.3 \\
Lipids $(\mathrm{g})$ & 12.1 & Niacin $(\mathrm{mg})$ & 0.1 \\
Saturated fatty acids $(\mathrm{g})$ & 3.3 & Folic acid $(\mu \mathrm{g})$ & 65.0 \\
Monounsaturated fatty acids $(\mathrm{g})$ & 4.9 & Cyanocobalamin $(\mu \mathrm{g})$ & 66.0 \\
Polyunsaturated fatty acids $(\mathrm{g})$ & 1.8 & Pyridoxine $(\mathrm{mg})$ & 0.12 \\
Cholesterol $(\mathrm{mg})$ & 410 & Retinol equivalents $(\mu \mathrm{g})$ & 227.0 \\
Iodine $(\mu \mathrm{gg})$ & 12.7 & Potassium $(\mathrm{mg})$ & 147 \\
Tocopherols $(\mu \mathrm{g})$ & 1.93 & Carotenoids $(\mu \mathrm{g})$ & 10 \\
Selenium $(\mu \mathrm{g})$ & 10 & Cholecalciferol $(\mu \mathrm{g})$ & 1.8 \\
\hline
\end{tabular}

Quantities represent an edible portion of about $100 \mathrm{~g}$.

Vezët janë konsideruar si një produkt ushqimor parësor për konsum njerëzor gjatë historisë, pasi ato sigurojnë pjesën më të madhe të të ushqyerit, siç sugjerohet nga shtesat rekomanduara ditore. Ndryshueshmëria në cilësinë dhe vlerat ushqyese të vezëve ka një ndikim të rëndësishëm në shëndetin e konsumatorëve. Njëkohësisht, mirëqenia dhe shumë faktorë të tjerë mund të ndikojnë në cilësinë e vezëve. Këta faktorë përfshijnë racën dhe tendosjen e shtresave, përbërjen dietike, shëndetin e zogjve, gjendjen e mjedisit dhe ruajtjen, përpunimin dhe trajtimin e vezëve (Attia,2016).

Prodhimi i vezëve në nivel botërorë arriti në 65 milion ton (FAO STATISTCS DIVISION-FAO STAT, 2012), që korrespondon me 1140 miliardë vezë për tryezë të prodhuara. Numri mesatar i linjave të pulave të vendosura në të gjithë botën është parashikuar në 4.93 miliardë (Komisioni Ndërkombëtar i EGG-IEC, 2012); me Kinën e renditur si lideri i lartë dhe një prodhim vezësh prej 28 Mt (43\%) dhe 800 milionë deri në një miliardë pula vojëse të vendosura. Bashkimi Evropian është i dyti në ranglistë, me 6.5 Mt (10\%) të vezëve të prodhuara dhe 290 milion pula vojëse, e ndjekur nga SHBA me 5.4 Mt (8.3\%) dhe 276 milion pula vojëse, India me 3.4 Mt (5.4\%) dhe 133 milion pula vojëse, Japonia me $2.5 \mathrm{Mt}(3.8 \%)$ dhe 121 milionë pula vojëse, Meksika me $2.38 \mathrm{Mt}$ 
(3.7\%) dhe 118 milion pula vojëse dhe së fundi, Brazili me 1.9 Mt (2.9\%) dhe 89 milion pula vojëse, duke u renditur në pozitën e 7-të (Bertechini, 2013).

\subsection{Kolesteroli}

Kolesteroli është një molekulë biologjike jashtëzakonisht e rëndësishme, që ka rol në strukturën e membranës, si dhe është një prekusorë për sintezën e hormoneve steroide, acideve biliare dhe vitaminës D. Të dy kolesterolet dietik, që sintetizohen “de novo”, transportohen përmes qarkullimit në grimcat e lipoproteinës. E njëjta gjë është për esteret e kolesterolit, forma në të cilën kolesteroli ruhet në qeliza. Për shkak të rolit të tij të rëndësishëm në funksionin e membranës, të gjitha qelizat shprehin enzimat e biosintezës së kolesterolit. Metabolizmi i kolesterolit tek njerëzit është kompleks. Kolesteroli mirret nga dieta (ekzogjene) ose sintetizohet de novo nga shumë qeliza të trupit (endogjen). Faktorët kryesorë në dietë që mund të rrisin nivelin e kolesterolit në gjak janë marrjet e larta të vetë kolesterolit, ose të yndyrnave të ngopura dhe kalorive të tepërta. Mëlçia është një nga vendet kryesore të sintezës së kolesterolit endogjen. Vendi i grumbullimit të kolesterolit në mëlçi është rregulluar fort dhe reflekton hyrjen e kolesterolit nga dieta, biosintezën e kolesterolit, sekretimin dhe marrjen e kolesterolit nga lipoproteinat plazmatike, poashtu shndërrimin e kolesterolit në acide biliare, rikthimin e kolesterolit në acide biliare dhe bilancit $\begin{array}{lllll}\text { acide nga } & \text { zorra } & \text { mëlçi Arnlod,2003). }\end{array}$ Kolesteroli i gatshëm është një substancë yndyrore, e prodhuar nga mëlçia e kafshëve dhe gjithashtu mund të merret në dietë përmes produkteve shtazore siç janë: mishi, shpendët, peshqit dhe produktet e qumështit.

Kolesteroli luan një rol të madh në shëndetin e zemrës së njeriut. Kolesteroli mund të jetë edhe i mirë edhe i keq. Lipoproteina me densitet të lartë (HDL) është kolesterol i mirë dhe lipoproteina me densitet të ulët (LDL) është kolesteroli i keq. Kolesteroli i lartë në serum është një faktor kryesor rreziku për sëmundjen kardiovaskulare të njeriut siç është sëmundja koronare e zemrës dhe goditja në tru që janë numër një për nga sëmundjet më të shpeshta në Amerikë (Tabas, 2002). Kolesteroli i tepërt në rrjedhën e gjakut mund të formojë pllakë (një depozitë e trashë, e fortë) në muret e arterieve. Krijimi i kolesterolit ose pllakës bën që arteriet të bëhen më të trasha, më të vështira dhe më pak fleksibël, duke u ngadalësuar dhe nganjëherë bllokuar rrjedhjen e gjakut në zemër. Kur qarkullimi i gjakut është i kufizuar, angina (dhimbjet në gjoks) mund të shfaqet (Hongbao Ma, 2004). 


\subsection{Kolesteroli në vezë}

Një vezë e zier me madhësi mesatare $(50 \mathrm{~g})$ përmban $78 \mathrm{kcal}$ energji, $6.29 \mathrm{~g}$ proteina, $0,56 \mathrm{~g}$ karbohidrate, dhe $5.3 \mathrm{~g}$ yndyrë totale, nga të cilat $1.6 \mathrm{~g}$ është e ngopur, $2.0 \mathrm{~g}$ është yndyrë e $\begin{array}{llllll}\text { pangopur } & \text { dhe } & 186 & \mathrm{mg} & \text { është }\end{array}$

Shumica e lipideve në vezë janë të përqendruara në të verdhën e vezës dhe përbëhen nga lipoproteinat, fosfolipidet, triacilglicerolet dhe kolesteroli. Depozitimi i kolesterolit në të verdhën e vezës mund të ndikohet gjithashtu nga ushqimi. Përfshirja e ushqimeve specifike në dieta të pulave vojëse që rriten në mënyrë komerciale, siç janë vajrat vegjetale të pasura me acide yndyrore të pangopura përdoren për të ndryshuar profilin e lipideve të vezëve dhe për të zvogëluar përmbajtjen e nöesterolit vezë (Faitarone,2013).

Studimet e hershme vëzhguese demonstruan një lidhje midis kolesterolit dietik dhe rrezikut për sëmundjet kardiovaskulare (CVD); megjithatë, këto studime fillestare nuk arritën të llogaritnin shumë ndryshime konfuze që kanë mundur të kufizojnë gjetjet e tyre, siç janë faktorët e tjerë të dietës dhe mënyra e jetesës. Studimet më të fundit epidemiologjike tregojnë zakonisht një mungesë të lidhjes midis kolesterolit dietik dhe / ose marrjes së vezëve dhe rrezikut të CVD në popullatën e përgjithshme. Sidoqoftë, duket se ka një marrëdhënie më të qëndrueshme midis marrjes së vezëve dhe CVD te diabetikët, megjithatë, kjo nuk është vërejtur gjithmonë. (N.Blesso,2018).

Në vitin 1968, Shoqata Amerikane e Zemrës (AHA) rekomandoi që konsumi i kolesterolit dietik të jetë jo më shumë se $300 \mathrm{mg}$ në ditë dhe theksoi jo më shumë se 3 të verdhë veze duhet të konsumohen në javë. Konsumi mesatar i kolesterolit dietik te të rriturit në SH.B.A. varion nga 200 në $350 \mathrm{mg} /$ ditë për shkak të dallimeve seksuale dhe moshës (Kuang, 2018). Megjithëse dieta me pak yndyrë e rekomanduar fillimisht nga National Cholesterol Education Program (NCEP) (NCEP) nuk ishte ndoshta dieta optimale,por kishte arsye të mira për rekomandimin e saj në pacientët që rrezikoheshin nga sëmundjet kardiovaskulare sepse ata duhet të kufizojnë marrjen e kolesterolit në më pak se 200 mg / ditë (si në dietën NCEP ashtu edhe në rekomandimet dietike të Shoqatës Amerikane të Zemrës. Gjate vrojtimeve në njerëz është parë që konsumi i lartë i kolesterolit dietik rritë nivelet e mosmarrjes së lipoproteinës me densitet të ulët (LDL) me afërsi 10\%, në mënyrë të varur nga sasia e marrjes së kolesterolit. Ulja me $10 \%$ e marrjes së nivelit të kolesterolit mund të mos duket shumë, por studimet e para të bëra kanë treguar se dieta e mbajtur dhe kolestiramina zvogëlojnë rrezikun koronar, një ulje e konsumit të LDL me $12 \%$ zvogëloi rrezikun koronar me $19 \%$. 


\section{DEKLARIMI I PROBLEMIT}

Duke pasur parasysh kolesterolin si substancë të rëndësishme dhe me ndikim të lartë në organizmin tonë, e gjithashtu prezencën e tij të lartë në vezë, është parë e dobishme analizimi i kësaj substance në tre lloje të vezëve të cilat ndryshojnë nga mënyra se si janë ushqyer pulat të cilat i kanë prodhuar vezët në fjalë. Kolesteroli është prekusor i disa funksioneve tejet të rëndësishme në organizëm por 
gjithashtu dhe sasia e lartë e tij në mund të shkaktojë sëmundje serioze të cilat jo rrallë herë përfundojnë me fatalitet.

\section{METODOLOGJIA}

\subsection{Mostrimi dhe përgatitja e mostrave}

Për hulumtimin e kolesterolit në të verdhën e vezës nga pulat vojëse janë marrë mostra në tre tipe të fermave: 
- Fermë e pulave vojëse me prodhim organik të vezëve

- Fermë që ka ushqyer pulat me misër kokërr dhe me barë livadhi dhe

- Fermë komerciale ku pulat janë ushyer me koncentrat

Në fermën e pulave vojëse me prodhim organik të vezëve që ndodhet në Komunën e Prizrenit në fshatin Arbanë janë marrë 10 kokrra vezë për analizë të mëtejme. Ferma ka afër 5000 pula vojëse të racave Amork, Leghorn, Njuhemshir etj. Pulat janë të gjeneratës F1 dhe F2 me një përqindje të vojtjes $67.5 \%$ në ditë. Organizimi i të ushqyerit në këtë fermë bëhet në tërësi nëpërmjet ushqimit organik si bari natyral, bari me drith të tërshërës poashtu natyral, lulelakër e egër, spinaq, mbeturina të pemëve etj, pasi që në këtë zonë ka dhe pemë të ndryshme që krejtësisht janë organike. Mineralet pulat i marrin nga rëra ndërsa ujin e kontrolluar dhe higjenik nga një pus brenda fermës. Duhet cekur që Prizreni ka 1,987 ekonomi familjare që mbarështojnë pula vojëse dhe ka 83,541 copë pula vojëse.

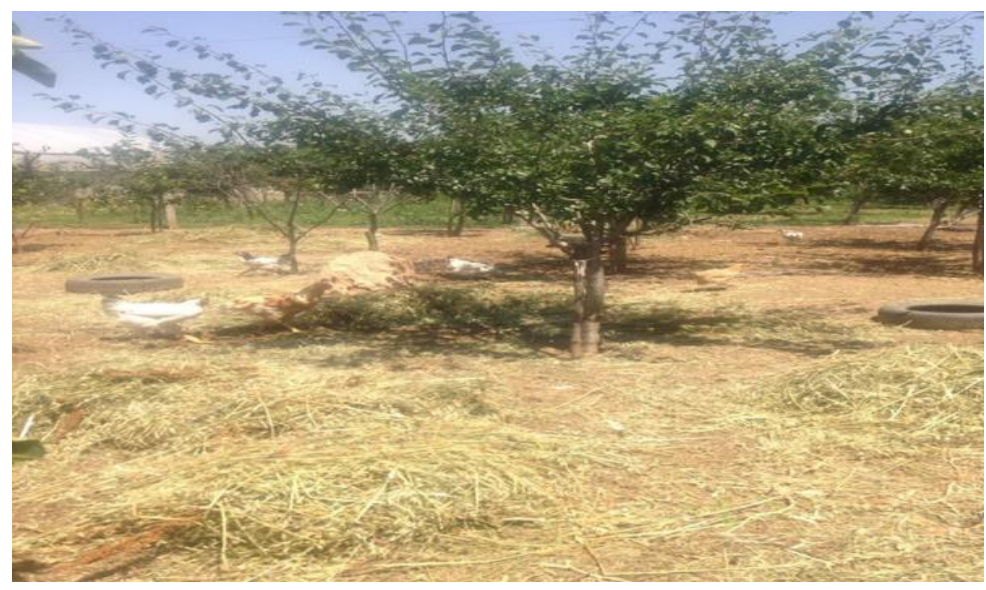

Figura1. Ambienti ku kullosin pulat që ushqehen në mënyre organike

Ferma që ka ushqyer pulat me misër kokërr dhe me barë livadhi ndodhet në Zhegër të Gjilanit, komunë kjo e cila ka 2108 ekonomi familjare që mbarështojnë pula vojëse dhe ka 137838 copë pula. Kapaciteti i fermës në fjalë është 200 copë pula të racës Amork dhe Leghorn. Pulat ushqehen me barë dhe me misër kokërr, përqindja e vojtjes është 65\% kurse mosha e pulave 9.5 muaj. 


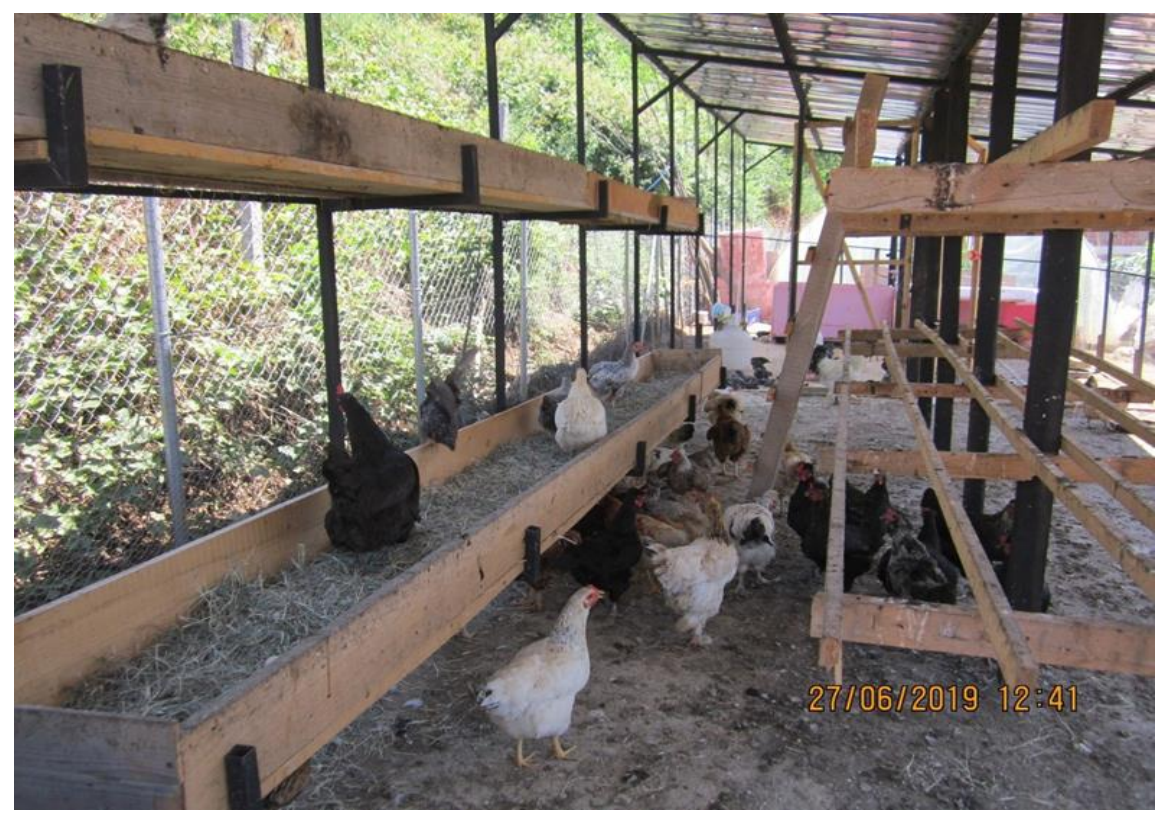

Figura 2. Ambient i fermës ekstensive

Ferma Komerciale e pulave vojëse ndodhet në Gjilan dhe kapaciteti i kësaj ferme është 12000 copë pula të racës Hajllan. Shumica prej tyre janë 8 muajshe kurse vojtja është $85 \%$. Sa i përket të ushqyerit ferma përgatitë vetë koncentratin duke u bazuar në përzierje përkatëse, të gjitha ushqimet janë të importuara. Sasia e konsumit të koncentartit është 125 gram për pulë brenda 24 orëve.

Tabela 2. Tabela e ushqimit të pulave për periudhën starter

\begin{tabular}{|c|c|c|}
\hline $\mathbf{N r}$ & Lënda e pare & $\begin{array}{c}\text { Sasia, } \\
\mathbf{k g}\end{array}$ \\
\hline 1 & Misër & 60 \\
\hline 2 & Sojë & 38 \\
\hline 3 & Vaj & 1 \\
\hline 4 & Sacox - premix & 1 \\
\hline & Totali & $\mathbf{1 0 0} \mathbf{~ k g}$ \\
\hline
\end{tabular}

Tabela 3. Tabela e ushqimit të pulave për periudhën grover

\begin{tabular}{|c|c|c|}
\hline $\mathbf{N r}$ & Lënda e pare & $\begin{array}{c}\text { Sasia, } \\
\mathbf{k g}\end{array}$ \\
\hline 1 & Misër & 62 \\
\hline 2 & Sojë & 26 \\
\hline
\end{tabular}




\begin{tabular}{|c|c|c|}
\hline \multicolumn{1}{|c|}{3} & Krunde & 6 \\
\hline 4 & Shkumës & 5 \\
\hline 5 & Clinacox - Premiks & 1 \\
\hline & Totali & $\mathbf{1 0 0} \mathbf{~ k g}$ \\
\hline
\end{tabular}

Tabela 4. Tabela e ushqimit të pulave për periudhën finisher

\begin{tabular}{|c|c|c|}
\hline Nr & Lënda e parë & $\begin{array}{c}\text { Sasia, } \\
\mathbf{k g}\end{array}$ \\
\hline 1 & Misër & 63 \\
\hline 2 & Sojë & 19 \\
\hline 3 & Krunde & 7 \\
\hline 4 & Shkumës & 10 \\
\hline 5 & Clinacox - premix & 1 \\
\hline & Totali & $\mathbf{1 0 0} \mathbf{~ k g}$ \\
\hline
\end{tabular}

\subsection{Puna eksperimentale}

\subsubsection{Procedura e ekstraktimit:}

- Butësisht hapni vezën. MOS E TRAZONI TË VERDHËN E VEZËS.

- Duke përdorur lëvozhgën, ndajeni të verdhën e vezës nga e bardha, dhe hudheni të bardhën. 
- Shtoni të verdhën e vezës në një gotë (mund ta perziheni tani) dhe regjistrojeni masën dhe vëllimin e saj. Nëse mundeni, hiqni shtresën e proteinës së bardhë që është në të verdhën e vezës. Përziheni vezën.

- Ndajeni të verdhën e vezës në 2 pjesë të barabarta dhe kryni hapat e mëposhtëm

- Shtoni një vëllim të barabartë acetoni në çdo tub. Kjo duhet të bëhet në një tub qelqi për centrifugim

- Përziheni materialin fuqishëm për 2 minuta

- Centrifugoni (100rpm, $15 \mathrm{~min})$

- Dekantoni acetonin

- Përsëritni të njëjtën tre herë

- Grumbulloni fraksionet e acetonit dhe në fund lejoni që acetoni të avullohet.

- Ekstrakti i acetonit duhet të përmbajë kolesterolin dhe pigmentet e të verdhës së vezës. Ruaj për testin tuaj të kolesterolit.

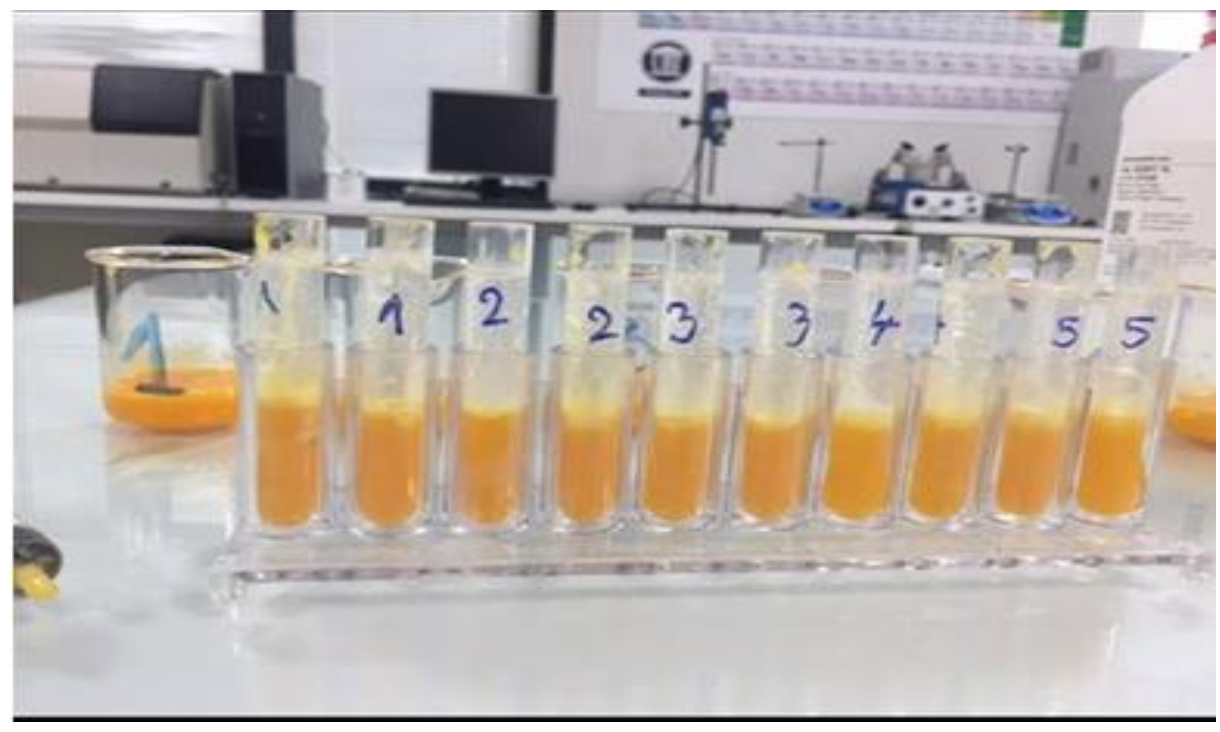

Figura 3. Ekstraktimi i mostrave

\subsubsection{Parimi i veprimit enzimatik të reagjentit të kolesterolit}

Reagjenti i kolesterolit përmban kolesterol-esterazë, kolesterol-oksidazë dhe peroksidazë të rrepës. 


\section{cholesterol $+O_{2} \stackrel{\text { cholesterdondore }}{\longrightarrow}$ cholestenone $+\mathrm{H}_{2} \mathrm{O}_{2}$}

$$
\mathrm{H}_{2} \mathrm{O}_{2}+\text { phenol }+4-\text { atrin o-antippine } \stackrel{H F}{\longrightarrow} \text { colored product }+\mathrm{H}_{2} \mathrm{O}
$$

Reaksioni enzimatik për prodhimin e kompleksit të ngjyrosur është me sa vijon:

Meqë vetëm kolesteroli i lirë është një substrat për oksidimin e kolesterolit, çdo ester i kolesterolit i pranishëm në mostër duhet së pari të hidrolizohet me ndihmën e enzimit kolesterol - esterazë. Kolesteroli i lire pastaj reagon me enzimin tjetër të njohur si kolesterol- oksidazë, me ç'rast formohet kolestenoni dhe lirohet perokisidi i hidrogjenit i cili në fund reagon me substance e njohur si 4-amino-antipirinë dhe në fund të reaksionit formohet produkti me ngjyrë, instensiteti i së cilit matet me anë të spektrofotometrit dhe është në proporcion të drejtë me përqendrimin e kolesterolit në mostër.

\subsection{Ecuria e punës:}

- Rivendosni fraksionin e acetonit në disa ml izopropanol (duhet ta dini sasinë)

- Përziheni mostrën e izopropanolit.

- Merr $1 \mathrm{ml}$ mostër dhe vendoseni në një tub tjetër.

- Shtoni $5 \mathrm{ml}$ izopropanol dhe perziheni mostren.

Përdorni tabelën më poshtë për të ndërtuar kurbën tuaj të kalibrimit dhe analizën e kolesterolit. Vendoseni reagjentët direkt në kivetën analitike.

Vërejtje: numëroni kivetat në maje dhe pastaj shtoni reagjent në kivetë konform udhëzimeve të dhëna në tabelën e mëposhtme. Ju duhet të shtoni të fundit reagjentin e kolesterolit dhe relativisht në të njëjtën kohë në çdo kivetë.

Pas shtimit të reagjentit në të gjitha kivetat, filloni (llogaritni) kohën. Mos i perziheni kivetat, por lëvizni ato lehtë me gishtin tuaj çdo 5 minuta. Inkuboni kivetat për 10 minuta.

Tabela 5. Protokoli i punës laboratorike

\begin{tabular}{|ll|l|l|l|l|l|l|l|}
\hline $\begin{array}{l}\text { Component } \\
\text { Përbërësi }\end{array}$ & $\begin{array}{l}\text { Blank - Prova e } \\
\text { Verbët }\end{array}$ & $\begin{array}{l}\text { Tube } \\
1\end{array}$ & $\begin{array}{l}\text { Tube } \\
2\end{array}$ & $\begin{array}{l}\text { Tube } \\
3\end{array}$ & $\begin{array}{l}\text { Tube } \\
4\end{array}$ & $\begin{array}{l}\text { Tube } \\
5\end{array}$ & $\begin{array}{l}\text { Tube } \\
6\end{array}$ \\
\hline
\end{tabular}




\begin{tabular}{|c|c|c|c|c|c|c|c|}
\hline Uji & $100 \mu \mathrm{L}$ & $90 \mu \mathrm{L}$ & $90 \mu \mathrm{L}$ & $90 \mu \mathrm{L}$ & $90 \mu \mathrm{L}$ & $90 \mu \mathrm{L}$ & $0 \mu \mathrm{L}$ \\
\hline $1 \mathrm{mg} / \mathrm{ml}$ standard & ------- & $10 \mu \mathrm{L}$ & ------- & ------- & ------- & ------- & ------- \\
\hline $2 \mathrm{mg} / \mathrm{ml}$ standard & $\begin{array}{l}------ \\
\end{array}$ & $\begin{array}{l}------ \\
\end{array}$ & $10 \mu \mathrm{L}$ & ------- & $\begin{array}{ll}------ \\
\end{array}$ & ------- & $\begin{array}{ll}------ \\
\end{array}$ \\
\hline $4 \mathrm{mg} / \mathrm{ml}$ standard & ------- & ------- & ------ & $10 \mu \mathrm{L}$ & ------ & ------- & ------ \\
\hline $8 \mathrm{mg} / \mathrm{ml}$ standard & ------- & ------ & ------- & ------ & $10 \mu \mathrm{L}$ & ------- & ------- \\
\hline Mostra e lipidit & ------- & ------- & ------- & ------ & ------- & $5 \mu \mathrm{L}$ & $50 \mu \mathrm{L}$ \\
\hline $\begin{array}{l}\text { Reagjenti } \\
\text { Kolesterolit }\end{array}$ & $1 \mathrm{ml}$ & $1 \mathrm{ml}$ & $1 \mathrm{ml}$ & $1 \mathrm{ml}$ & $1 \mathrm{ml}$ & $1 \mathrm{ml}$ & $1 \mathrm{ml}$ \\
\hline
\end{tabular}

Lexoni absorbancën në 500 nm në UV-VIS.

Përdorni grafikun (kurbën kalibruese) për të përcaktuar mg / ml të kolesterolit në mostrën tuaj.

\section{PREZANTIMI DHE ANALIZA E REZULTATEVE}

\subsection{Prezantimi i rezultateve}

Tabela 6. Kolesteroli në vezët komerciale 


\begin{tabular}{llll}
$\begin{array}{l}\text { Emërtimi } \\
\text { mostrës }\end{array}$ & Pesha e të kuqes së vezës $(\mathrm{g})$ & $\begin{array}{l}\text { Përqendrimi i kolesterolit në të } \\
\text { kuqen e vezës së holluar }(\mathbf{m g} / \mathbf{m l})\end{array}$ & $\begin{array}{l}\text { Përqendrimi } \\
\text { kolesterolit } \\
\text { vezës }(\mathbf{m g})\end{array}$ \\
\hline K1 & $\begin{array}{c}\text { total } \\
\text { kuqen }\end{array}$ & $\begin{array}{c}\text { i } \\
\text { e }\end{array}$ \\
K2 & 18.46 & 0.690 & 152.84 \\
K3 & 15.83 & 1.015 & 192.80 \\
K4 & 18.36 & 0.820 & 180.66 \\
K5 & 16.83 & 0.911 & 183.98 \\
K6 & 17.29 & 0.800 & 165.98 \\
K7 & 17.82 & 0.580 & 124.02 \\
K8 & 15.79 & 0.720 & 136.42 \\
K9 & 14.56 & 0.987 & 172.44 \\
K10 & 15.55 & 0.910 & 169.80 \\
K11 & 16.70 & 0.465 & 93.180 \\
K12 & 13.41 & 1.270 & 204.36 \\
K13 & 17.10 & 0.830 & 170.31 \\
K14 & 14.95 & 1.080 & 209.89 \\
K15 & 18.06 & 1.160 & 272.34 \\
\hline
\end{tabular}

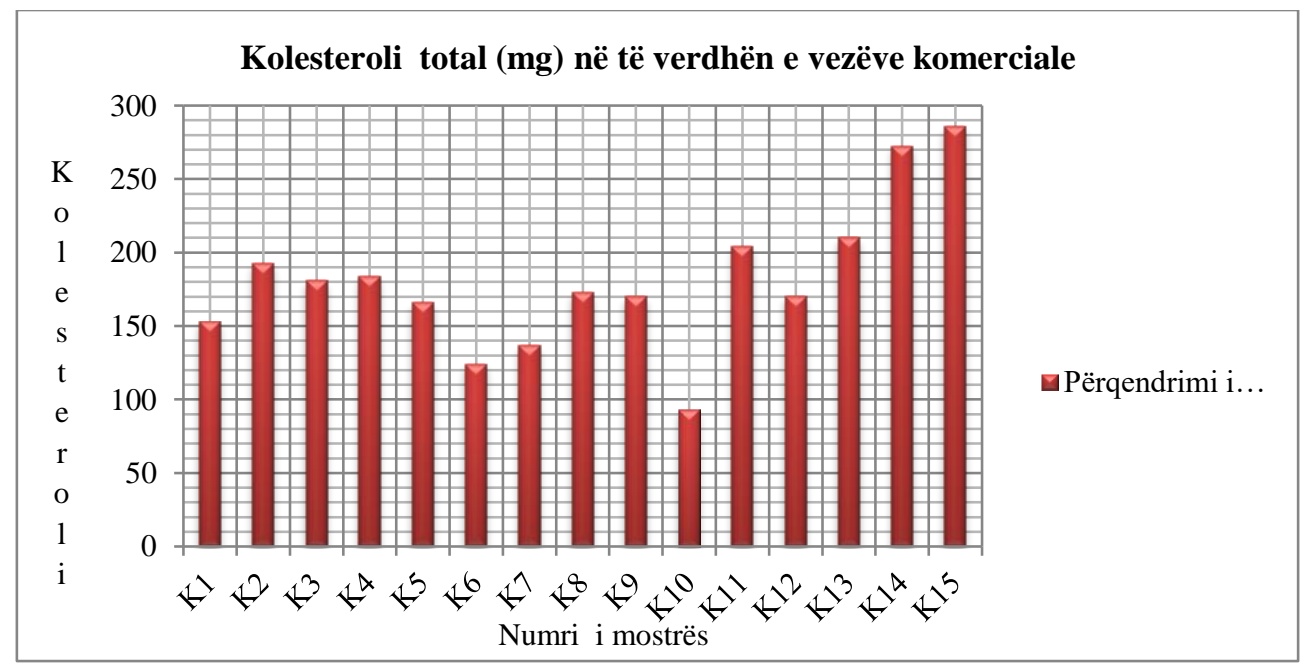

Figura 4. Kolesteroli total në të verdhën e vezëve komerciale

Tabela 7. Kolesteroli në të verdhën e vezëve ekstenzive 


\begin{tabular}{llll} 
E1 & 16.73 & 0.290 & 64.590 \\
E2 & 18.41 & 0.504 & 120.62 \\
E3 & 17.34 & 0.529 & 119.24 \\
E4 & 18.83 & 0.627 & 153.48 \\
E5 & 14.79 & 0.715 & 137.47 \\
E6 & 15.63 & 0.422 & 85.740 \\
E7 & 18.23 & 0.850 & 201.44 \\
E8 & 15.40 & 0.979 & 195.99 \\
E9 & 18.24 & 0.807 & 191.35 \\
E10 & 19.14 & 0.997 & 248.07 \\
\hline
\end{tabular}

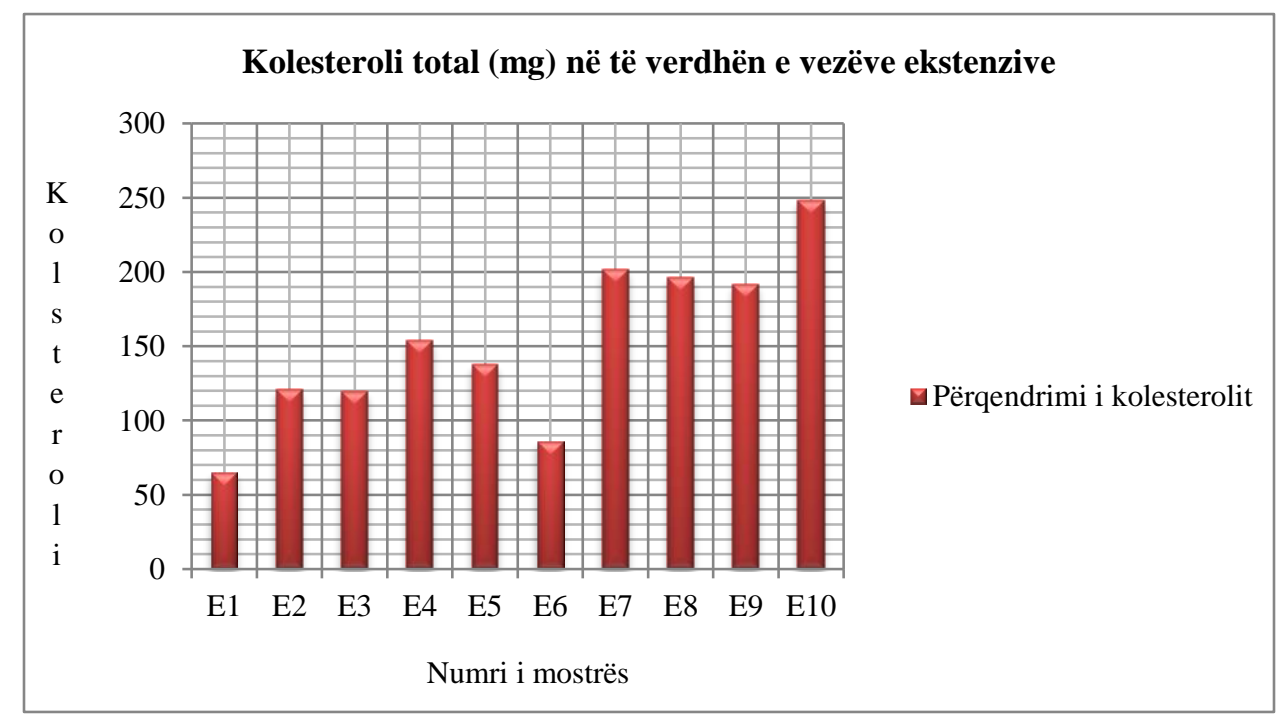

Figura 5. Kolesteroli toal në të verdhën e vezëve ekstenzive

Tabela 8. Kolesteroli në të verdhën e vezëve organike

\begin{tabular}{llll}
$\begin{array}{l}\text { Emërtimi } \\
\text { i mostrës }\end{array}$ & Pesha e të kuqes së vezës $(\mathrm{g})$ & $\begin{array}{l}\text { Përqendrimi i kolesterolit } \\
\text { në të kuqen e vezës sër } \\
\text { holluar }(\mathrm{mg} / \mathrm{ml})\end{array}$ & $\begin{array}{l}\text { Pëdrimi total i kolesterolit } \\
\text { në të kuqen e vezës (mg) }\end{array}$ \\
\hline $\mathbf{O} 1$ & 18.26 & 1.140 & 270.61 \\
$\mathbf{0 2}$ & 19.58 & 0.297 & 73.810 \\
\hline
\end{tabular}




\begin{tabular}{llll}
\hline 03 & 15.33 & 0.720 & 143.48 \\
04 & 16.21 & 0.490 & 103.25 \\
05 & 19.67 & 0.724 & 185.13 \\
06 & 14.55 & 0.819 & 154.91 \\
07 & 16.63 & 0.877 & 189.59 \\
08 & 17.32 & 1.065 & 239.79 \\
09 & 15.93 & 0.589 & 121.89 \\
010 & 19.38 & 1.076 & 271.08 \\
\hline
\end{tabular}

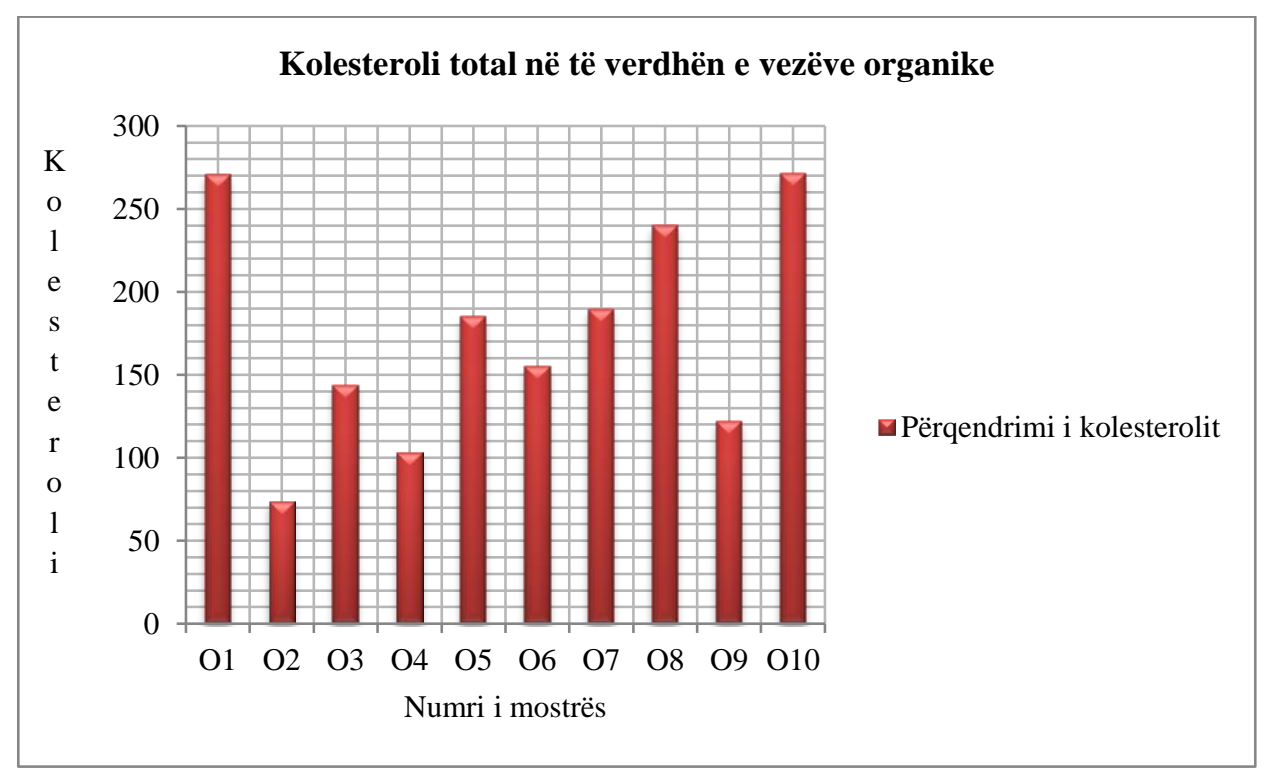

Figura 6. Kolesteroli total në të verdhën e vezëve organike

\subsection{Analiza e rezultateve}

Sipas Departamentit Amerikan të Bujqësisë (U.S. Department of Agriculture) një vezë e madhe ka rreth 186 mg kolesterol - të gjitha këto gjenden në të verdhën e vezës edhe pse në literaturë 
hasen edhe të dhëna tjera në raport me përqendrimin e kolesterolit në vezë, mirëpo në të gjitha këto dominon fakti që në një vezë të madhësisë mesatare përqendrimi i kolesterolit në të kuqen e vezës sillet rreth $200 \mathrm{mg}$.

Te analiza e kolesterolit në vezët komerciale mënyra e mostrimit ka qenë spontane. Janë analizuar gjithsej 15 vezë komerciale. Fillimisht është bërë matja e të verdhës së vezës në gr e pastaj llogaritja e kolesterolit në të verdhën e vezës së holluar për të përfunduar me llogaritjen e kolesterolit total në të verdhën e vezëve komerciale.

Rezultatet e marra pas analizave spektroskopike tregojnë për një mesatare të pëqendrimit të kolesterolit në të kuqen e vezëve komerciale prej 180.97 mg, përqendrim ky i cili është në përputhje me të dhënat e Departamentit Amerikan të Bujqësisë (U.S. Department of Agriculture) lidhur me përqendrimin mesatar të kolesterolit në vezë. Nga të dhënat tabelare vërejmë se jo çdoherë sasia e të verdhës së vezës është në raport të drejtë ose determinon përqendrimin total të kolesterolit në vezë. P. sh. nëse marrim dhe analizojmë mostrën K11 vërejmë se edhe përkundër faktit që masa e të verdhës së vezës në këtë mostër është relativisht e vogël (13.41 gr) përqendrimi i kolesterolit në mostrën e holluar e rrjedhimisht edhe përqendrimi total në mostrën e analizuar është më i lartë (204.36mg) krahasuar me disa nga mostrat tjera të cilat përmbajnë masë fillestare më të madhe të të verdhës së vezës. Në fund, rezultatet e analizave të vezëve komerciale në raport me mostrat tjera të vezëve të analizuara (vezët ekstenzive dhe vezët organike) tregojnë për një përqendrim mesatar më të lartë të kolesterolit në të verdhën e vezës.

Rezultatet e marra nga analizat e bëra në vezët ekstenzive tregojnë edhe këtu për një përqendrim mesatar të kolesterolit në të verdhës e vezëve brenda rekomandimeve të dhëna nga Departamenti Amerikan i Bujqësisë (U.S. Department of Agriculture) në raport me përqendrimin mesatar të kolesterolit në të kuqen e vezës (186 mg). Nga dhjetë mostra të analizuara vërejmë se mesatarje e përqendrimit të kolesterolit në të verdhën e vezëve është $151.799 \mathrm{mg}$. Nëse këto rezultate i krahasojmë me mesataren e rezultateve të marra nga mostrat e vezëve komerciale dhe atyre organike shohim se përqendrimi mesatar i kolesterolit në këtë lloj të vezëve është më i ulët.

Sikurse te vezët komerciale edhe në këtë lloj të vezëve vërejmë se masa e të verdhës së vezës jo domosdoshmërisht determinon përqendrimin total të kolesterolit në të verdhën e vezës. P.sh. nëse e analizojmë mostrën E1 dhe E5 shohim se përkundër faktit që në mostrën E1 e verdha e vezës peshon më shumë (16.73 gr) krahasuar me mostrën E5 (14.79 gr) në fund nga analizat vërejmë se 
përqendrimi total i kolesterolit në mostrën E1 (64.590 mg) është dukshëm më i ulët krahasuar me mostrën E5 (137.47mg).

Edhe tek lloji i vezëve organike si në dy rastet e mëparshme rezultatet e marra nga analizat e bëra tregojnë për përqendrim mesatar të kolesterolit brenda rekomandimeve të dhëna nga Departamenti Amerikan i Bujqësisë (U.S. Department of Agriculture) në raport me përqendrimin mesatar të kolesterolit në të kuqen e vezës (186 mg). Mostrimi edhe këtu ka qenë spontan dhe nga dhjetë mostra të analizuara vërejmë se mesatarja e përqendrimit të kolesterolit në të verdhën e vezëve është $175.354 \mathrm{mg}$. Nëse këto rezultate i krahasojmë me mesataren e rezultateve të marra nga mostrat e vezëve komerciale dhe atyre ekstenzive shohim se përqendrimi mesatar i kolesterolit në këtë lloj të vezëve është më i ulët krahasuar me vezët komerciale ndërsa pak më i lartë në raport me vezët e analizuara ekstenzive. Edhe në këtë lloj të vezëve sikurse në të llojet e mëparshme mund të vërejmë shmangie nga pritja që masa e të verdhës së vezës determinon përqendrimin e kolesterolit.

\section{KOKNLUZIONE DHE REKOMANDIME}

Pas analizës së pëqendrimit të kolesterolit në 35 mostra të vezëve mund të konkludojmë me sa vijon: 
- Mesatarja e përqendrimit të kolesterolit në të tri grupet e analizuara nuk tejkalon limitet ose rekomandimet e dhëna nga Departamenti Amerikan i Bujqësisë (U.S. Department of Agriculture) në raport me përqendrimin mesatar të kolesterolit në të kuqen e vezës (186 mg).

- Mesatarja e përqendrimit të kolesterolit në të verdhën e vezëve komerciale ka qenë pak më e lartë krahasuar me vezët ekstensive dhe ato organike.

- Mesatarja e përqendrimit të kolesterolit në të verdhën e vezëve ekstensive ka qenë pak më e ulët krahasuar me vezët komerciale dhe ato organike.

- Jo çdoherë pesha e të verdhës së vezës është në raport të drejtë me përqendrimin e kolesterolit.

- Përveç mënyrës së të ushqyerit, me gjasë përqendrimi i kolesterolit në vezë determinohet edhe nga një mori faktorësh tjerë të cilët këtë çështjë e bëjnë mjaft komplekse.

Pas përfundimit të këtij hulumtimi konsumatorëve dhe kolegëve tanë ju rekomandojmë me sa vijon:

- Të bëhen analiza më të detajizuara në raport me pëqendrimin e kolesterolit në të verdhën e vezës, në kuptim të përcaktimit të faktorëve të ndryshëm që ndërlidhen dhe ndikojnë në një mënyrë apo tjetrën në përqendrimin e këtij parametri shumë të rëndësishëm.

- Të evitohet konsumimi i tepërt i vezëve (nevoja ditore për kolesterol është 300 mg), konkretisht mos të konsumohen më shumë së 2-3 vezë të plota brenda ditës edhe pse Shoqata Amerikane e Zemrës (The American Heart Association) sugjeron një vezë (ose dy të bardha vezë) në ditë për njerëzit që i hanë ato, si pjesë e një diete të shëndetshme.

- Për ata me sëmundje të zemrës, diabeti tip 2 ose personat me nivel të lartë të kolesterolit të keq (LDL), Shoqata Amerikane e Zemrës (AHA) dhe Programi Kombëtar i Arsimit të Kolesterolit (NCEP) sugjerojnë kufizimin e marrjes së kolesterolit në 200 miligram në ditë. 
- Të kontrollohen përbërësit ushqimor dhe të zbatohen standardet në raport me mënyrën e duhur të të ushqyerit të pulave, në veçanti ushqimi i cili përgatitet dhe përdoret në fermat komerciale.

- Të verifikohen me anë të analizave të ndryshme laboratorike deklarimet e kompanive të ndryshme të cilat deklarojnë se produktet e tyre janë të certifikuara dhe në treg figurojnë si produkte bio ose organike.

\section{REFERENCAT}

A. Attia Y., A. Al-Harthi M., M. Shiboob M. (2014). Evaluation of Quality and Nutrient Contents of Table Eggs from Different Sources in the Retail Market. Italian Journal of Animal Science Volume 13, 2014 - Issue 2. 
Abeyrathne E.D.N.S., Lee H.Y., Ahn D.U. (2013). Egg white proteins and their potential use in food processing or as nutraceutical and pharmaceutical agents. Poultry Science, Volume 92, Issue 12, Pages 3292-3299.

Arnold D.R., Kwiterovich Jr P.O. (2013). CHOLESTEROL | Absorption, Function, and Metabolism. Science Direct. Encyclopedia of Food Sciences and Nutrition (Second Edition).

Bertechini A G., Mazzuco H. (2013). The table egg: a review. Ciênc. agrotec. vol.37 no.2, Lavras.

C.H.S. Ruxton., E. Derbyshire., S. Gibson. (2010). The nutritional properties and health benefits of eggs. Nutrition \& Food Science 40(3):263-279.

Faitarone ABG, Garcia EA., Roça R., Vercese F. (2013). Cholesterol Levels and Nutritional Composition of Commercial Layers Eggs Fed Diets with Different Vegetable Oils. Revista Brasileira de Ciência Avícola 15(1):31-37.

Kuang H., Yang F., Zhang Y., Wang T., Chen G. (2018). The Impact of Egg Nutrient Composition and Its Consumption on Cholesterol Homeostasis. Hindawi, Volume 2018, Article ID 6303810, 22 pages.

Ma H. (2004). Cholesterol and Human Health. Nature and Science, 2(4).

N. Blesso Ch., Fernandez M. L. (2018). Dietary Cholesterol, Serum Lipids, and Heart Disease: Are Eggs Working for or Against You? Nutrients v.10 (4); 2018 Apr PMC5946211.

Song WO., Kerver JM. (2000). Nutritional contribution of eggs to American diets. Pub Med.gov. J Am Coll Nutr. (5 Suppl):556S-562S. 
